Article

\title{
The Refugees' Right to the Center of the City and Spatial Justice: Gentrification vs Commoning Practices in Tarlabaşı-Istanbul
}

\author{
Charalampos Tsavdaroglou \\ Department of Human Geography, Planning and International Development, University of Amsterdam, \\ 1018 WC Amsterdam, The Netherlands; E-Mail: tsavdaroglou.ch@gmail.com
}

Submitted: 1 April 2020 | Accepted: 21 May 2020 | Published: 31 August 2020

\begin{abstract}
During the recent refugee crisis and following the common statement-agreement between the European Union and Turkey (18 March 2016), more than half a million refugees have been trapped in Istanbul. Although the vast majority is living in remote areas in the perimeter of the city, there is a remarkable exception in the central neighborhood of Tarlabaşı. Over the decades, this area has become a shelter for newcomers from eastern Turkey and, recently, for thousands of refugees from the Middle East and Africa. In this neighborhood, refugees with the support of local and international solidarity groups establish communal houses, social centers, and collective kitchens, creating an example of commoning practices, mutual help, and transnational togetherness in the urban core. At the same time, over the past few years, Tarlabaşı has been the target of gentrification policies that aim to dislocate poor residents and refugees and to transform the area into a highincome residential area and a tourist destination. Thus, ongoing urban conflict is taking place for the right to the center of the city. This article follows the Lefebvrian concept of 'the right to the city' and Soja's and Harvey's notion of 'spatial justice,' taking also into account the discussion on the spatialities of 'urban commons' and 'enclosures.' It combines spatial analysis, participatory observation, and ethnographic research, and its main findings concern the refugees' daily efforts against social segregation and exclusion shaped by commoning practices for spatial justice, visibility, and the right to the center of the city.
\end{abstract}

\section{Keywords}

commoning practices; exclusion; Istanbul; refugees; right to the city; segregation; spatial justice; Tarlabaşı

\section{Issue}

This article is part of the issue "Cities of Inclusion-Spaces of Justice" edited by Anja Nygren (University of Helsinki, Finland) and Florencia Quesada (University of Helsinki, Finland).

(C) 2020 by the author; licensee Cogitatio (Lisbon, Portugal). This article is licensed under a Creative Commons Attribution 4.0 International License (CC BY).

\section{Introduction}

Istanbul is an emerging global city where frenetic redevelopment and gentrification projects have been taking place over the last years. One of the most controversial plans is the Tarlabaşı Renewal Project, which aims to convert a very central neighborhood to a high-class area with hotels, shopping centers, and luxurious apartments. However, there is a remarkable delay due to the resistance from the local community. Tarlabaşı is a unique mosaic of people, from Romani, Kurdish, and Muslims from eastern Turkey to members of the trans and gay community, newcomers from Africa, and refugees from the war zones of the Middle East who rent cheap rooms in poor-quality houses or occupy abandoned buildings. Concomitantly, a network of self-organized solidarity initiatives and community centers supports the residents and organizes collective activities and anti-gentrification struggles. Although there is extensive literature (Kuyucu \& Ünsal, 2010; Öz \& Eder, 2018) on gentrification processes in Istanbul, there are few studies that focus on the articulation of gentrification with refugees' commoning practices which claim the right to the city and spatial justice in the case of the Tarlabaşı neighborhood. This article aims to explore questions about the potentialities of refugees to co-live and co-inhabit in the center of the city. 
This article is based on critical scholarship on gentrification (Lees, 2012; Ley, 1996; Smith, 1999) and on the works of Lefebvre (1968/1996), Soja (2010) and Harvey $(1973,1996)$, which have aptly examined spatial inequalities as well as urban social movements and proposed the powerful concepts of the right to the city and spatial justice. Also, for the research, the aforementioned notions are linked to the discussion on urban commons and spatial enclosures (An Architektur, 2010; Chatterton, 2010). Although the concept of urban commons has become a key concept for radical scholars and social movements, except for a few studies (Trimikliniotis, Parsanoglou, \& Tsianos, 2015; Tsavdaroglou, 2018b), there is not an indepth effort to connect it with the refugees' right to the city and spatial justice. As such, the article takes also into account the approach of autonomy of migration (De Genova, 2017; Papadopoulos \& Tsianos, 2013) to conceptualize the potentialities for agency and commoning activities of the newcomers. Thus, it aims to examine and analyze the ongoing gentrification project versus the refugees' commoning practices in the contested neighborhood of Tarlabaşı, through the conceptual tools of the refugees' right to the city and spatial justice.

The article is based on socio-spatial mapping and ethnographic participatory research. Primarily, various papers and surveys for the history of Tarlabaşı and the ongoing renewal project were obtained and analyzed. 10 life stories and 30 open-ended interviews were also carried out, as well as numerous informal conversations with locals and refugees who are tenants or squatters in the Tarlabaşı neighborhood of Istanbul. The fieldwork took place for 15 months from summer 2018 to autumn 2019, during which I visited the neighborhood almost daily, participated in local meetings in community centers, and collected data in gatherings in tea shops, cafes, and restaurants, on the streets, in local markets, public spaces and peoples' homes. The research participants were over 18 years old and mainly from Syria, Palestine, Nigeria, Egypt, Morocco, Somalia, and Turkey. For confidentiality reasons and to respect anonymity, the interlocutors' names have been changed to pseudonyms.

The article has the following structure: The first section examines the theoretical positions focusing on the concepts of gentrification, the right to the center of the city, spatial justice, and commoning practices. The following two sections present the gentrification project in Tarlabaşı and the spatial commoning practices of the newcomers. The final section gives some suggestions for critical scholarship on the importance of refugees' commoning practices that claim the right to the center of the city.

\section{Right to the Center of the City and Spatial Justice: Gentrification vs. Commoning Practices}

The so-called 'gentrification' of cities has been a dominant neoliberal urban transformation strategy in recent decades. From the early studies of the 1960s and
1970 s, it became clear that the dislocation of certain social groups is the main goal of gentrification, and not a side effect (Glass, 1964). More specifically, gentrification is considered to have its roots in the so-called 'revanchism,' which according to Smith (1999, p. 98) "blends revenge with reaction" and it is expressed as a "vendetta against workers...immigrants and gays, people of color...homeless people, squatters" (Smith, 1999, p. 98), all of whom are accused of having "stolen" the city, and especially the center of the city, "from a white middle class that sees the city as its birthright" (Smith, 1999, p. 98). Thus, an orchestrated effort for the reappropriation of the city centers through massive gentrification and urban renewal projects that combine economic (Smith, 1999) and cultural (Ley, 1996) motives, started initially in the USA, then in Western Europe and gradually across the globe. However, it should be noted that gentrification is not a homogenous process and it may take distinct forms in different ways in different places (Lees, 2012; Luke \& Kaika, 2019). Decolonial urban theory especially has shown that gentrification "is not a simple export of urban formations and developmental patterns from global North to global South" (Jeffrey, McFarlane, \& Vasudevan, 2012, p. 1251). The article takes into consideration the differentiating processes and responds to the significant lack of studies on recent urban conflicts between gentrification projects and refugees' commoning practices in Istanbul.

Along with gentrification projects and against their motives and policies, there are a plethora of urban social movements that claim the right to the city and spatial justice for all.

The concept of the right to the city was first developed in the work of Henri Lefebvre (1968/1996), who at the end of the 1960 s proposed that the right to the city is expressed as "a superior form of rights: right to freedom, to individualization in socialization, to habitat and to inhabit" (Lefebvre, 1968/1996, p. 173). Several scholars have expanded the notion of the right to the city, for instance, Purcell $(2002$, p. 100) argues that it is a call for "urban politics of the inhabitant" and according to Dikeç (2001, p .1789), "it is not simply the right of property owners, in which case policies like zero tolerance might have been legitimized...but of all who live in the city." Furthermore, it should be noted that Lefebvre put particular emphasis on the right to the center of the city. In his words, the right to the city "would also cover the right to the use of the center, a privileged place, instead of being dispersed and stuck into ghettos (for workers, immigrants, the 'marginal')" (Lefebvre, 1968/1996, p. 34). Building on the previous argument, Merrifield (2011) offers a renewed conceptualization of the Lefebvrian right to centrality that underlines how in times of urban agglomerations and suburbanization, special consideration should be given not to "a simple visiting right...no tourist trip down memory lane, gawking at a gentrified old town, enjoying for the day a city you've been displaced from, but a right to participate in life at the core, to be in 
the heat of the action" (Merrifield, 2011, p. 475). This argument is particularly useful in examining the conflict between the ongoing gentrification processes in the Tarlabaşı neighborhood, which is a very central neighborhood in Istanbul, and the potentialities of the refugees' right to the center of the city in terms of participating in urban social life and claiming spatial justice.

At this point, it is essential to briefly examine the importance of the concept of spatial justice, which has a long tradition in critical geography literature. Until the '90s, the discussion on spatial justice revolves between scholars such as Davies (1968), who examined the conditions of distribution, and as Harvey (1973), who focused on the modalities of production and introduced the notion of 'territorial social justice.' Harvey's (1992, 1996) approach on "the forms of oppression as sources of injustice," (cited in Dikeç, 2001, p. 1786) based on Young's idea of the 'unoppressive city' that 'must be open and accessible to all," (Young, 1990, p. 319) is a turning point in the discussion of spatial justice. Later, Soja (2009), taking into account the previous considerations, suggests that spatial justice primarily "involves the fair and equitable distribution in space of socially-valued resources and the opportunities to use them." An argument that I will show later is linked to the concept of commons. Moreover, Soja identifies that "the three most familiar forces shaping locational and spatial discrimination are class, race, and gender," which are particularly relevant to the examined neighborhood of Tarlabaşı, and finally he highlights the crucial interweaving of the right to the city and spatial justice for a "new spatial consciousness" (Soja, 2010, p. 96).

The aforementioned concepts of the right to the city and spatial justice could enrich the discussion on commons and especially urban commoning practices. According to several scholars (De Angelis, 2007; Hardt \& Negri, 2009; Tsavdaroglou, 2019), commons usually refer to those collective social relations that maintain, resist or claim material or immaterial territories outside of the market-led or state-led management and are constituted by the triad: common-pool resources, commoning, and community. According to De Angelis (2007, p. 1), commons "are necessarily created and sustained by 'communities' i.e., by social networks of mutual aid, solidarity, and practices of human exchange that are not reduced to the market form." These social practices and activities of mutual care, reciprocity, support, and sharing constitute the so-called commoning, a term that has recently acquired increasing interest among radical scholarship. As Linebaugh (2010) argues, the common "as an action it is thus best understood as a verb rather than as a 'common pool resource."' Particularly significant is that the practices of commoning are directed against multiple socio-spatial enclosures; thus, commoning always has a spatial character as it aims to (re)shape, (re)invent, and (re)produce egalitarian and unoppressive spaces of togetherness and coexistence. Consequently, here is the social and spatial locus of the interconnection of urban commons with the right to the city and spatial justice. As Stavrides (An Architektur, 2010, p. 17) underlines, the right to the city "can be produced through encounters that make room for...new values, new dreams, new collective experiences. And this is... a way to see commons beyond the utilitarian horizon." Furthermore, Chatterton (2010) aims to combine commons with the concept of spatial justice and argues that "the quest for greater spatial justice...can be sharpened...through the use of the 'common' as both a political imaginary and vocabulary, and also as a material aspiration and organising tool" (Chatterton, 2010, p. 626). Consequently, urban commoning practices and experiences open potentialities for reimagining and rediscovering solidarity and justice in urban spaces against the manifold ways of spatial injustices and the prohibitions of access to the right to the city.

The abovementioned conceptualization of commons can help to unpack the less-visible urban commoning practices of refugees who claim their right to the city and spatial justice. Usually, refugees are seen as people in need of humanitarian assistance or targets of xenophobia and racism. Thus, they are seen as victimized or stigmatized and criminalized. However, in recent years, several studies mainly from the so-called 'autonomy of migration' approach (De Genova, 2017; Papadopoulos \& Tsianos, 2013) call for attention to the active agency of the moving population who are trying to transcend and cross the multiple physical and social borders. During these crossings, refugees often develop networks of solidarity, exercise sharing practices, and exchange knowledge, activities that may acquire an urban character and express claims to spatial justice and the right to the city (Trimikliniotis et al., 2015; Tsavdaroglou, 2018b).

Thus, the main research question of this article is how refugees' urban commoning practices and relations can contest gentrification policies to claim the right to the city and more accurately to the center of the city and mobilize everyday spatial justice.

\section{3. "Tarlabaşı Will Remain a Nostalgic Photo on Your Mobile Phone": Spatial Policies of Gentrification and Injustice}

Gentrification not only demolishes buildings but also destroys people's and city's memories. Tarlabaşı will remain a nostalgic photo on your mobile phone. It's like the photos we have on our mobile phones from our home in Syria before the war and now it doesn't exist because it has been bombed. Now, Tarlabaşı, this second home of ours will also be demolished. In Syria, we may at some point be able to repatriate and rebuild our houses, but here it will be impossible to stay in the future luxurious neighborhood. (Mohamed, Syrian refugee, personal interview, 10 June 2019)

Istanbul has evolved in recent decades into a rapidly expanding global city with a booming construction industry, extensive renewal and gentrification projects, hun- 
dreds of gated communities, and impressive megaprojects (Aksoy, 2012; Erdi-Lelandais, 2013; Öz \& Eder, 2018). These practices are depicted by Lovering and Turkmen (2011) as "bulldozer neoliberalism" and as Karaman (2013, p. 716) underlines, they "have been used as a tool of dispossession, expropriating residents and uprooting them from their social networks." At the same time, Istanbul is the city where more than half a million refugees have arrived in the last six years from the war zones of the Middle East, Central Asia, and Africa (Asylum Information Database \& European Council on Refugees and Exiles, 2019). Most of the newcomers are living in poor neighborhoods, deprived areas, and slums on the outskirts of the city. However, the Tarlabaşı neighborhood, a very central area where some thousands of newcomers find shelter, is a remarkable exception. It is also the place in Istanbul where one of the most ambitious and controversial gentrification projects has taken place in the last fifteen years.

Tarlabaşı is located in Beyoğlu district next to the city's commercial and tourist center, less than 200 meters from the glitzy Istiklal street and the iconic Taksim square. The area of Tarlabaşı was always a multinational neighborhood, in which until the mid-twentieth century the residents were mainly Orthodox Greeks, Armenians, Jews, and Muslims. However, after the nationalistic violent pogroms of 1955, the area was abandoned by the non-Muslims and re-inhabited during the three following decades of Istanbul's rapid industrialization by lowincome rural migrants from the Black Sea region and central and eastern Turkey. Moreover, during the military regime of the 1980s, many Kurds lost their land in the conflicted areas of southeast Turkey and forced to migrate to Istanbul to find jobs and settle (Islam, 2010; Ünsal, 2015). Thus, many of them rented cheap apartments in the Tarlabaşı neighborhood, as it is "very central for accessing jobs" (Can, 2020, p. 142). Furthermore, the Tarlabaşı neighborhood has been home "to many
Romani musicians and dancers who have taken advantage of the cheap rent and proximity to Taksim, Istanbul's entertainment district" (Corry, 2013).

In the late 1980s, the design of the eight-lane Tarlabaşı Boulevard (Figure 1) connecting Taksim square with the Fatih peninsula, and separating "the beauty and the beast" (Pinar, 2011)-that is, the poor neighborhood-from the emerging commercial area of Beyoğlu, was a turning point in the history of the neighborhood. Indeed, the Boulevard functions as a physical and social border and especially in the night hours when police patrol the road entrances to the Tarlabaşı area. This is largely associated with the transformation of the area south of Tarlabaşı Boulevard into the city's main tourist, entertainment, and commercial district. While north of the Boulevard the impoverished enclave of the Tarlabaşı neighborhood is located; an area that provides a relatively safe place to unregistered and disenfranchised migrants, sex workers, and the transgender community. Sex workers and the transgender community moved to Tarlabaşı after the massive gentrification in the 1990s and 2000s in other parts of Beyoğlu, like the Karaköy and Galata districts that closed and banned most brothels in these areas.

During the last decades, Tarlabaşı Boulevard has become a place for street sex work linked to precarious and vulnerable conditions as sex workers are exposed to greater violence from clients and police controls and the threat of sexual exploitation networks. Concomitantly, newcomer refugees from the war zones of the Middle East and North Africa arrived in Tarlabaşı in mid-2000 and especially during the current refugee crisis. The vast majority of Tarlabaşı residents are working in informal and precarious jobs as sex workers, waste collectorsrag pickers, peddlers, and street vendors, selling food in the nearby tourist areas for very low pay (Can, 2020; Türkün \& Şen, 2009). Other employments linked to the region's residents include temporary labor in the textile

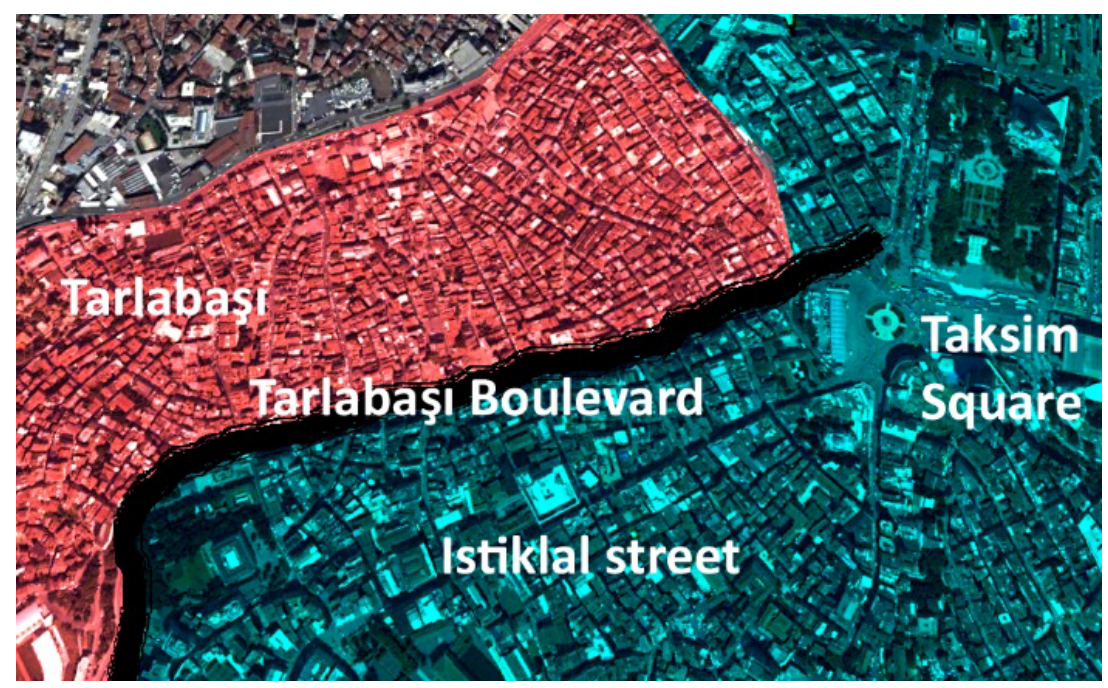

Figure 1. Tarlabaşı Boulevard separates the Tarlabaşı neighborhood from Taksim square and the Istiklal street area. Source: Author. 
and stamping industry, in the construction sector, call centers, and hair salons, as well as waiting and cleaning staff in restaurants, cafés, tea places, and night clubs, while, as mentioned, most of the Romani people are working as musicians and dancers (Corry, 2013; Kuyucu \& Ünsal, 2010; Talocci, 2011).

Since the initial construction of the Boulevard, the residents of Tarlabaşı have struggled for their right to the center of the city against the imposed spatial injustice and marginalization while authorities and mainstream media stigmatize the area with negative attributions, such as "prostitution and drug dealers' area" or "the Bronx of Istanbul" (Sakizlioglu \& Uitermark, 2014). The territorial stigmatization is regimented by declaring the neighborhood as a no-go area (Figure 2) and a dangerous crime zone, a characteristic strategy with similar processes and effects across the globe that makes it "easy for the authorities to justify special measures, deviating from both law and custom, which can have the effect...of destabilizing and further marginalizing their occupants" (Wacquant, 2007, p. 69).

It becomes apparent that spatial injustice and enclosure of the right to the center of the city has intensified with the special measures introduced under the 2005 Law no. 5366 voted by the Turkish Parliament, which transferred "extraordinary powers to local authorities to declare urban renewal areas and to implement development plans in run-down areas within historic heritage sites" (Aksoy, 2012, p. 104). Law 5366 became popular as the Tarlabaşı Law, as it was initially linked to the socalled Tarlabaşı Renewal Project. The first phase of the project concerns an area of around 20,000 square meters with an explicit aim to "renew 278 buildings in 9 blocks of the Tarlabaşı neighborhood" (Kuyucu \& Ünsal, 2010) and to transform them into luxurious residential buildings, offices, shopping malls, cafés, and hotels. The second phase concerns 21 more blocks and with a final goal of gentrifying the whole neighborhood. The project is advertised with slogans such as "Tarlabaşı will be a rose gar- den in three years. Tarlabaşı is a poisoned princess and we are healing her. Tarlabaşı will be a safe place" (Can, 2018). These advertisements cover the high metal fences that surround the area while a cleaning out agenda was implemented with the first evictions in 2011.

Indicative are the words of Assala, a refugee woman from Syria who had lived for three years in the neighborhood until she received a visa to join her relatives in Sweden:

Tarlabaşı is changing very fast, it is gentrified. In my house, I have a window overlooking the neighborhood, the poor people's homes. However, two months ago, a large hotel was built and unfortunately, it destroyed my view. It is very annoying. So, I think I am leaving at the right time, and in a little while, Tarlabaşı as we knew it will be gone, it will be filled with luxury hotels and apartments. It is already happening. (personal interview, 10 May 2019)

Real estate capital enters Tarlabaşı with the massive demolition of building blocks and the rebuilding of modern housing for high economic strata residents. These instances of spatial injustice and prohibition of access to the center of the city echo Merrifield's (2011) description that the global metamorphosis of the cities' centers took place as "a vicious process of dispossession...spitting [the poor] out of the gentrifying center, forcing poor urban old-timers and vulnerable newcomers to embrace each other...out on assorted zones of social marginalization, out on the global banlieue" (Merrifield, 2011, p. 474). Indeed, the commodification and touristification of the area have already started. Airbnb apartments and boutique hotels have appeared in the perimeter of the neighborhood. Moreover, the prohibition to the right to the center and spatial injustice are produced along with gender, ethnicity, cultural norms, and class lines (Öz \& Eder, 2018). Characteristic are the words of Aisha, a Nigerian transgender woman who has been living in Tarlabaşı for

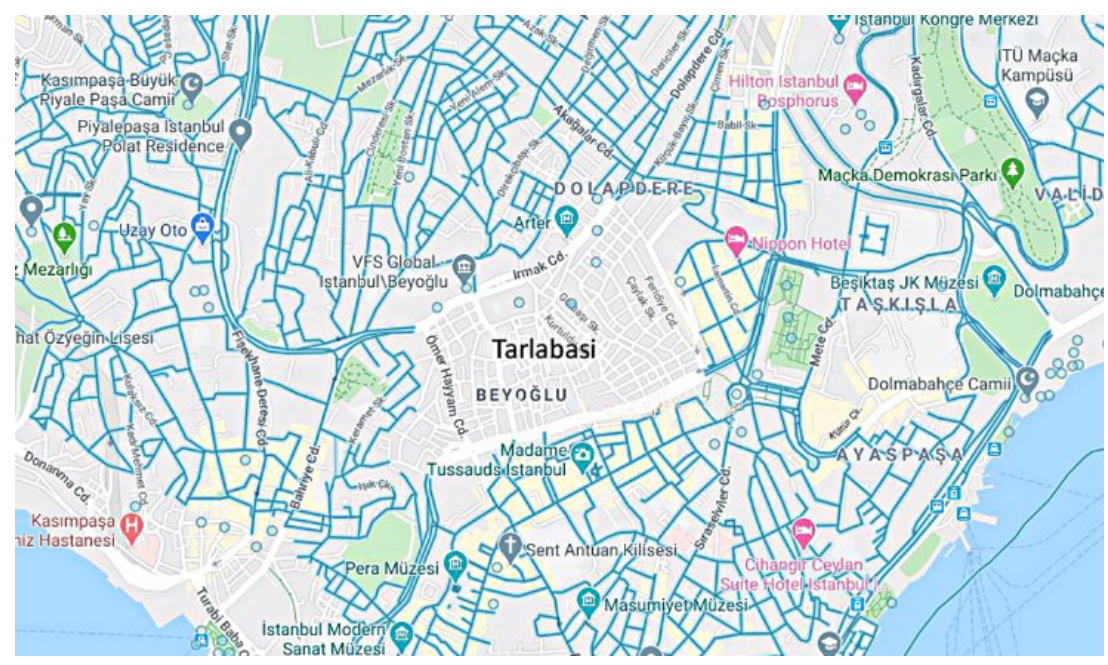

Figure 2. Google Maps' screenshot. The Tarlabaşı neighborhood is missing with no available street view. 
the last four years; she is also a member of the Istanbul LGBTQ Solidarity Association: "For me, as a poor, black, and transgender woman, it is a constant battle to survive in the center of Istanbul," and as she stresses, with the gentrification project "increased rent prices but also police control, transphobia, violence against transgender people and migrants, thus we face an uncertain and vulnerable future" (personal interview, 12 April 2019).

However, the threat of forced displacement and "the pressure of the local municipality and the construction company to sell the buildings or flats at very low prices" (Can, 2013, p. 100) inspired a residents' self-organized association to defend their rights. Thus, although many of the old residents have been displaced, local struggles have prevented a radical change of the neighborhood and the plan has been delayed for almost 15 years. Thus, there is only one block of new luxurious buildings being constructed at the moment across the Tarlabaşı Boulevard. The backstreets are still inhabited by Kurdish and Romani residents, transgender people, homosexuals, and newcomers from Africa and the Middle East. This social amalgamation and plural identity of the neighborhood opens new possibilities of spatial commoning relations and the potentiality to reimagine the right to the center of the city and spatial justice.

\section{Refugees' Spatial Commoning}

I am living in Tarlabaşı the last two years and I would say that for refugees, Tarlabaşı is a very good neighborhood, it is right in the center of Istanbul, but it still keeps the features of a neighborhood, people are smiling at you in the street, the neighbors know each other. Also, besides the Syrians, there are many Kurds, other Arabs from Palestine, Iraq, and Egypt, and many from Africa, all of them are very friendly. We are all humans, with our difficulties, with our dreams, with our different cultures, but we are all equal, we are all humans. Maybe for a tourist when he or she hears the word Tarlabaşı it means fear, but for me, it means home, neighborhood, friends. (Karima, Syrian refugee; personal interview, 21 June 2019)

Beyond and against the gentrification policies and the mainstream stigmatization rhetoric of Tarlabaşı, there is a plethora of less visible social relations, gatherings, and gestures of daily commoning practices as well as self-organized refugees' and locals' solidarity groups and community centers that claim the right to the center of the city and spatial justice.

Behind the facade of flashy new high buildings across the Tarlabaşı Boulevard and the hydra of real estate speculation, there is a hidden neighborhood of microcommons. Tarlabaşı is a labyrinth of narrow streets and dilapidated buildings marked by a deafening absence of state support and municipal social services. However, it is the home of various marginalized communities and a sanctuary for many newcomers-refugees from the
Middle East and Africa. According to novelist Ahmet Ümit, Tarlabaşı over time "had taken refuge those who had been chewed up and spit out [by life] and who struggled to keep on their feet" (Ümit, 2014, p. 168). Indeed, Fatima, a Syrian refugee woman who has been living the last three years in the neighborhood highlights:

I remember the first months when we, the Syrians, came to Tarlabaşı and everybody was trying to help us, both immigrants from other countries and older residents of the neighborhood, such as Kurds. They gave us food, clothes, and the kids were all playing together. Especially if you look at the micro-society of children, they will teach you a lot about how people can communicate across the borders of their nationalities. (personal interview, 16 April 2019).

In the transnational micro-society of Tarlabaşı, social, religious, racial, and even gender borders are negotiated, modified, and troubled. For instance, a Kurdish lady cooks and takes care of her disabled Syrian neighbor, a transgender woman receives help from her Nigerian neighbor to hack the electricity line, an Iraqi woman lowers a bucket from her window and her husband in the street fills it up with groceries with the help of Romani kids, a Syrian family uses the bath of their Turkish family neighbors every week to have a shower, Romani musicians offer impromptu music lessons to refugee kids in a local coffee shop, while every evening during Ramadan a big makeshift table is prepared on the street for the iftardinner for the whole neighborhood. Alireza, an Iranian refugee, says that "if a neighbor is very poor and cannot afford to cook, the rest of the neighbors offer him or her food, I don't think that this could happen in neighborhoods where only Turks are staying" (personal interview, 21 March 2019). Also, Aisha, a Nigerian transgender woman says that:

Tarlabaşı is the only haven for the transgender community in the center of Istanbul, and with the support of an LGBT organization we have established a collective house to take care of homeless or sick transgender people, Turkish and migrants from other countries as well as older retired transgender people who are not able to work. (personal interview, 12 April 2019)

Thus, these invisible commoning practices are essential in the everyday life and survival of Tarlabaşı residents. Although they are of different religions, ethnicities, languages, and cultural backgrounds they share a sense of cohabitation and togetherness. In the words of Ali, a Syrian refugee resident:

Tarlabaşı is a very poor neighborhood, but also a friendly neighborhood, it reminds me of something of the atmosphere and social life in Syria. I mean that in Tarlabaşı the residents care about each other, there are social relationships of care. Moreover, if anyone 
has a problem, the neighbors, no matter where they are from, care about them or her and help or protect them, children from different countries also play together, and often you can see women cooking together or washing their carpets together all along the way in the streets. (personal interview, 8 May 2019)

Moreover, it is this environment of Tarlabaşı, created daily by various peoples and cultures, which produces an amalgamation of populations and provides a tolerant space for newcomers. In the words of Syrian refugee Mustafa:

I have stayed in several neighborhoods outside of the city center. Now I live in Tarlabaşı and I like it much more here, because for me the most important difference between Tarlabaşı and other neighborhoods is that there are not so many Syrians here, to be precise, no national community dominates the neighborhood. There are people from many different countries. So here, there is not much social control exercised by a community that I felt in other more national homogenous neighborhoods. In Tarlabaşı there is much ethnic diversity, thus I feel freer, I prefer it. It is also next to the city center, so I have more opportunities for socialization and for getting to know the city better. (personal interview, 11 December 2018)

However, neighborhood coexistence in Tarlabaşı sometimes involves tensions and conflicts that divide residents into different communities. It is not uncommon that older residents, such as Turkish and Kurds, express negative views towards the newcomers and this might make refugees from Africa and the Middle East "keeping...in the periphery" (Genç, 2017, p. 125). Romani and transgender people are also occasionally victims of internal stigmatization. Similarly, political activists might be treated as foreigners, while often there is a gap between the expectations of migrants and the support they receive as their urgent daily needs cannot always be covered by the solidarity activities of political groups (Genç, 2017). However, "even though conflicts and tensions did occur, people watched out for each other and were careful not to let conflicts escalate" (Sakizlioglu \& Uitermark, 2014, p. 1373). Most importantly, beyond internal controversies, all residents recognize the gentrification project and the increasing police control as the most crucial problem in the neighborhood. While the transgender community, which includes people of different origins, has developed a secret slang called lubunca to "communicate without police or clients understanding what they say" (Dangerfield, 2015). It contains terms from other languages, including Arabic, Armenian, Greek, and French, and "constantly evolves to remain secretive" (Dangerfield, 2015).

It is important to emphasize here, that apart from the daily micro-commoning practices and the occasional instances of internal difficulties described, the residents of Tarlabaşı many times collectively claim their right to the city and spatial justice and organize or participate in numerous protests. For instance, the death of Eylül Cansın in 2015, a 24-year-old transgender sex-worker, led to a social protest organized by the Tarlabaşı transgender community against police brutality. Moreover, the local transgender community, among them transgender refugees, actively participates every year in the gay pride march and in the international Women's Day marches of the 8th of March and 25th of November. Equally important is the involvement of Tarlabaşı, mainly Kurds and transgender residents, in the 2013 Gezi Park protest (Potuoğlu-Cook, 2015; Tsavdaroglou, 2018a) and the emblematic direct action of burning the gigantic advertisement banners of the Tarlabaşı renewal project on the facades of the under-construction luxurious buildings across the Tarlabaşı Boulevard. Finally, one of the most significant collective organizations between locals and newcomers, property owners and renters to defend their rights against the gentrification project, was the establishment in 2008 of the Association for Solidarity with Tarlabaşı Property Owners and Renters. The neighborhood united beyond their differences against the common threat, and the association "has successfully mobilised almost all residents" (Kuyucu \& Ünsal, 2010, p. 1492) and "called upon the help of many activist experts, including lawyers, journalists [and] planners" (Sakizlioglu \& Uitermark, 2014, p. 1377).

In the words of Tamara, a refugee Syrian woman who has lived for the last five years in the neighborhood:

We, refugees and locals, the residents of Tarlabaşı, are against gentrification, the neighborhood has to be preserved, there are so many memories, so many daily stories of people who are poor, who are suffering and have found shelter in Tarlabaşı. In a few years, the neighborhood will be unrecognizable. Many old buildings have already been vacated or demolished, and hotels are being built and tourists are flocking close to Taksim Square. (personal interview, 8 May 2019)

Moreover, in addition to the above mobilizations, it should be mentioned that the Tarlabaşı neighborhood has a long tradition of collective action and solidarity organization. Over the last decade, several refugee solidarity groups and community centers have emerged in the wider area of the neighborhood (Figure 3), and are motivated by commoning practices in a self-managed way. For instance, in the heart of the neighborhood, the Tarlabaşı Community Center (2010) "tries to make equal conditions in terms of the participation of city life for people in Tarlabaşı" and "protecting people live in the Tarlabaşı area who are excluded from social life and live in poverty and deprivation of fundamental rights...and raising awareness among Tarlabaşı inhabitants in terms of violation of their rights." Likewise, Mutfak, a selforganized migrant solidarity kitchen, which has been run- 


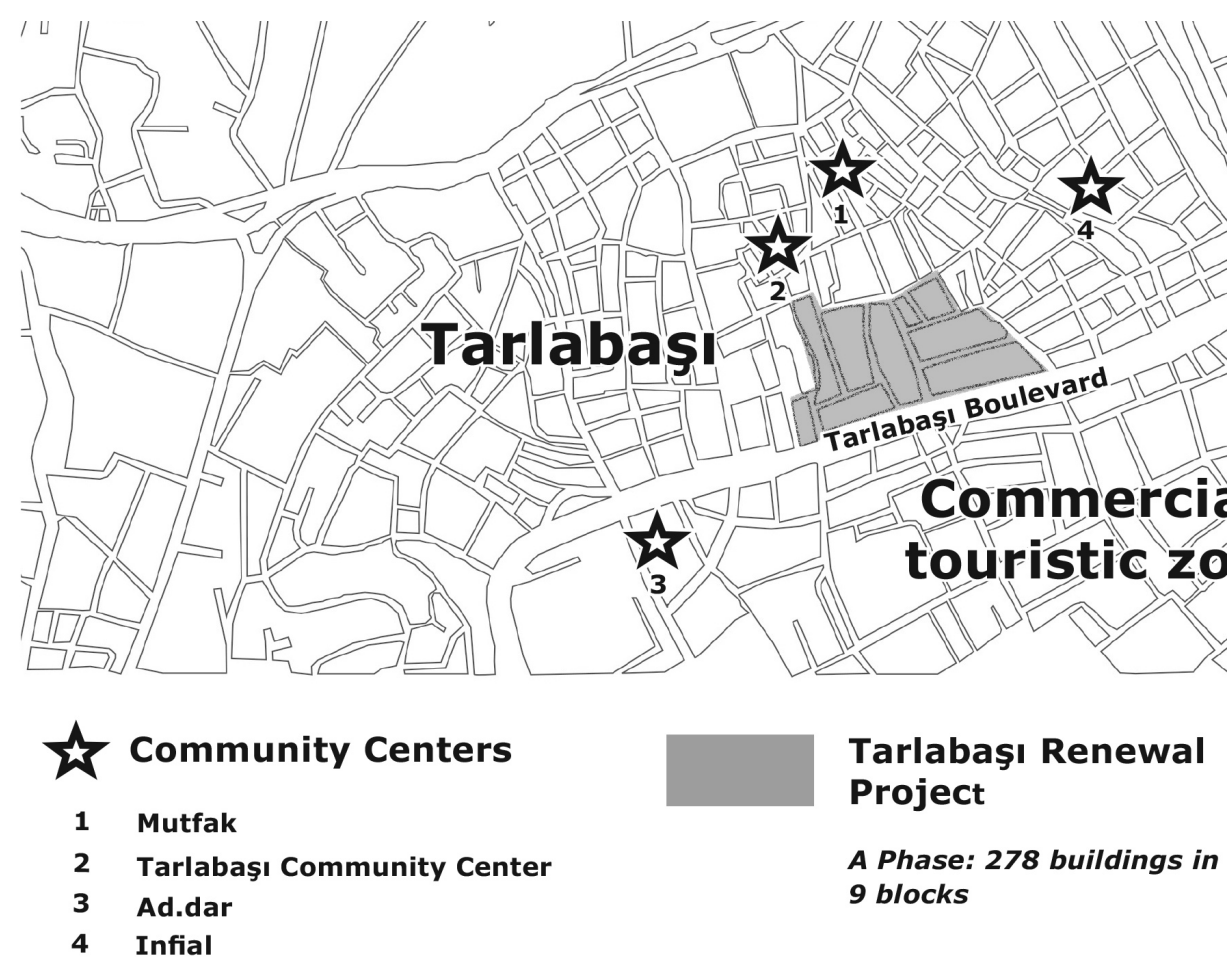

Figure 3. Positions of community centers and the Tarlabaşı renewal project. Source: Author.

ning since 2012, aims to build "a social center formed by migrants themselves, as well as a space of interaction where different struggles would interact and have a propagative quality" (Genç, 2017, p. 124).

Mutfak is formed by the Istanbul Migrant Solidarity Network and organizes several activities that aim to "create connections between disparate migrant groups, as well as with members of the MSN [Migrant Solidarity Network] and the residents of the neighborhood" (Genç, 2017, p. 124). These activities include collective music events, children's workshops, Turkish, Kurdish, Arabic, German, French and English language courses, legal assistance to refugees on their status and rights, support to refugee children to enroll and attend public schools, connect refugees and trade unions and placing refugee issues on trade union agenda, solidarity campaigns about refugees' working conditions. While the main activity is the collective kitchen, it is not, as Mutfak collective's (2016) own statement describes:

Like any other kitchen. It has neither cooks nor customers. Here, everybody is a cook and all the food is shared. The kitchen belongs to the neighborhood and everybody. Everyone is welcome. So come, bring your ideas and let's share our skills and solidarity.

Also, the Mutfak collective gives special emphasis to non-monetary social relations, and as Genç, a member of Mutfak explains: "The Kitchen was an experiment where the monetary relations of daily life were practically abolished, interpersonal relations were formed based on solidarity, and the voluntary reciprocity be- tween migrants and non-migrants was a central theme" (Genç, 2017, p. 124).

Another neighborhood initiative called Infial, an anarchist social center describes itself as a common space which "can be seen as a small step for supporting organization and mobilization to...a large spectrum of solidarity: from anarchist, anti-capitalist, ecological solidarity to animal liberation and queer solidarity." (Infial, 2017) Although Infial is not a migrant-based association, it aims to establish an egalitarian and non-hierarchical collective space that can forge social and political bonds between political activists and the local community. Collective cooking with neighbors, clothes that are donated and offered, queer workshops and events, environmental and working struggles, and actions against gentrification are some of the practices that bring together political activists and residents.

Finally, Ad.dar ('The Home,' in Arabic) is a volunteerbased community center which supports Syrian and Palestinian families to rebuild their lives. Currently, Ad.dar (2019) organizes "activities and classes, as well as various forms of practical, social, and emotional assistance for children, families, and youths. Ad.dar is unique in that the organization is....inclusive of all, completely regardless of sect or creed. All are welcome."

As it becomes apparent, all the collective practices of solidarity and commoning described shape the transnational community of Tarlabaşı daily and support the local struggle of resistance against the transformation of the neighborhood that causes the forced displacement of the urban poor. At the same time, everyday practices of mutual help, togetherness, and cohabitation produce 
a shared space of visibility, tolerance, and negotiation among the different residents, which marks a common basis for claiming their right to the city and spatial justice in the center of Istanbul.

\section{Conclusion}

The spatialities of commoning social bonds created daily in the Tarlabaşı neighborhood are like the clotheslines between apartment windows that are hidden away from the tourist's gaze and that make up and sustain the newcomers' transnational community. Gentrification aims to cut these symbolic rolling strings-links and prohibit refugees and the urban poor from having access to the center of the city. The socio-spatial conflict around who has the right to live in Tarlabaşı neighborhood and thus who has the right to inhabit the heart of Istanbul offers an interesting case study to outline three main arguments for social awareness on refugees' spatial justice.

First, this research shows that the gentrification project is like a process of invasion in Tarlabaşı that produces spatial injustice and deprives refugees of the right to the center of the city in three ways. Primarily, it is the physical enclosure of fencing, demolition of buildings, and police control; secondly, it is the destruction of residents' social relations through dislocation and touristification of the area; and finally, it is the propaganda of negative stigmatization and criminalization of the marginalized residents. All these aspects constitute a clear case of spatial enclosures. However, gentrification policies do not develop and follow a fixed procedure. In contrast, they can be challenged and opposed. Indeed, the gentrification project has been delayed for almost 15 years and the Tarlabaşı neighborhood, in the heart of Istanbul, is still open to newcomers. This reminds us of Massey's famous position "for the space" (Massey, 2005), which is always open to the possibilities of coexistence of multiplicity and heterogeneity, as she points out, space is "always under construction...it is never finished; never closed" (Massey, 2005, p. 9).

Second, the aforementioned concept of open space could shed some light on the potentialities of refugees' commoning practices to transform the Tarlabaşı neighborhood to a possible common space. Openness means that refugee residents of Tarlabaşı, together with solidarity groups, can contest dominant urban taxonomies, resist spatial enclosures, stigmatization, and unjustness and at the same time open the center of the city by making their rights visible and participating in urban social life. Thus, commoning practices can potentially contest the dominant stigmatization rhetoric (Kirkness, 2014; Wacquant, 2007), that taxonomizes such places as 'ghettos,' 'the dark side,' or 'black holes' of cities (McFarlane, 2008). Against these spatial "stereotypes...and well-worn cliché" (Roy, 2011, p. 225), refugees' commoning practices in Tarlabaşı correspond to what Roy (2011) suitably describes as "terrain of habitation, livelihood, self-organization, and politics" (Roy, 2011, p. 223). They reflect practices of 'every- day' and 'silent' resistance (Bayat, 2013), and mark places where, in the words to Hardt and Negri (2009, p. 254), "the multitude of the poor...invents strategies for survival, finding shelter and producing forms of social life, constantly discovering and creating resources of the common through expansive circuits of encounter."

Third, taking into account the previous positions, I argue that the circuits of encounter, dynamic or silent resistance and everyday networks of solidarity can operate as a catalyst for the mobilization and utilization of the refugees' right to the city and spatial justice. Without overlooking the multiple internal difficulties, I argue that the social relations of commoning help the neighborhood community to strengthen a collective consciousness and empower bonds of solidarity. As Chatterton (2010, p. 628) reminds us, "as we seek spatial justice, we mustn't forget that we are commoners," which means in the case of refugees that emerging commoning values of caring, sharing and mutual help are the catalyst to activate spatial justice and the right to the city towards an "unoppressive city" as "openness to unassimilated otherness" (Young, 1990, p. 319).

\section{Acknowledgments}

This scientific publication is an outcome of the RE-HOUSING project, which has received funding from the European Union's Horizon 2020 research and innovation program under the Marie Skłodowska-Curie grant agreement No. 795992. I would like to thank all the participants, refugees, and activists who contributed to the development of this work. Special thanks to the reviewers and llektra Kyriazidou for their useful comments.

\section{Conflict of Interests}

The author declares no conflict of interest.

\section{References}

Ad.dar. (2019). About us. Ad.dar Center. Retrieved from http://www.addarcenter.org/about-us

Aksoy, A. (2012). Riding the storm: 'New Istanbul.' City, 16(1/2), 93-111.

An Architektur. (2010). On the commons: A public interview with Massimo De Angelis and Stavros Stavrides. e-flux, 2017(17). Retrieved from https://www. e-flux.com/journal/17/67351/on-the-commonsapublic-interview-with-massimo-de-angelisandstavros-Stavrides

Asylum Information Database, \& European Council on Refugees and Exiles. (2019). Turkey: Statistics. Asylum in Europe. Retrieved from https://www.asylum ineurope.org/reports/country/turkey/statistics

Bayat, A. (2013). The quiet encroachment of the ordinary. Chimurenga. Retrieved from https:// chimurengachronic.co.za/quiet-encroachment-ofthe-ordinary-2 
Can, A. (2013). Neo-liberal urban politics in the historical environment of Istanbul. The issue of gentrification. Planlama, 23(2), 95-104.

Can, A. (2018). Territorial stigmatization during an urban regeneration project: The example of Tarlabasi. AESOP. Retrieved from https://aesopyoung academics.wordpress.com/2018/05/25/territorialstigmatization-during-an-urban-regenerationproject-the-example-of-tarlabasi

Can, A. (2020). A recipe for conflict in the historic environment of Istanbul: The case of Tarlabasi. ACME, 19(1), 131-162.

Chatterton, P. (2010). Seeking the urban common: Furthering the debate on spatial justice. City, 14(6), 625-628.

Corry, M. S. (2013). Gentrification and Romani dance in Istanbul. Kuri: Journal of the Dom Research Centre, 3. Retrieved from http://www.domresearchcenter. com/journal/30/v3-06.html

Dangerfield, M. B. (2015). Inside Istanbul's trangender community. Vice. Retrieved from https:// www.vice.com/sv/article/mvxayp/inside-istanbulstrangender-community

Davies, B. (1968). Social needs and resources in local services. London: Michael Joseph.

De Angelis, M. (2007). The beginning of history. London: Pluto.

De Genova, N. (Ed.). (2017). The borders of "Europe": Autonomy of migration, tactics of bordering. Durham, NC: Duke University Press.

Dikeç, M. (2001). Justice and the spatial imagination. Environment and Planning A: Economy and Space, 33(10), 1785-1805.

Erdi-Lelandais, G. (2013). Citizenship, minorities and the struggle for a right to the city in Istanbul. Citizenship Studies, 17(6/7), 817-836.

Genç, F. (2017). Migration as a site of political struggle. An evaluation of the Istanbul migrant solidarity network. Movements, Journal for Critical Migration and Border Regime Studies, 3(2), 117-132.

Glass, R. (1964). London: Aspects of change. London: MacGibbon and Kee.

Hardt, M., \& Negri, A. (2009). Commonwealth. Cambridg, MA: The Belknap Press of Harvard University Press.

Harvey, D. (1973). Social justice and the city. Baltimore, MD: John Hopkins University Press.

Harvey, D. (1992). Social justice, postmodernism and the city. International Journal of Urban and Regional Research, 16, 588-601.

Harvey, D. (1996). Justice, nature, and the geography of difference. Oxford: Basil Blackwell.

Infial. (2017). What is infial? Infial. Retrieved from https://infial.noblogs.org/what-is-infial

Islam, T. (2010). Current urban discourse. Urban transformation and gentrification in Istanbul. Architectural Design, 80, 58-63.

Jeffrey, A., McFarlane, C., \& Vasudevan, A. (2012). Rethinking enclosures: Space, subjectivity and the com- mons. Antipode, 44(4), 1247-1267.

Karaman, O. (2013). Urban renewal in Istanbul: Reconfigured spaces, robotic lives. International Journal of Urban and Regional Research, 37(2), 715-733.

Kirkness, P. (2014). The cités strike back: Restive responses to territorial taint in the French banlieues. Environment and Planning A, 46(6), 1281-1296.

Kuyucu, T., \& Ünsal, Ö. (2010). 'Urban transformation' as state-led property transfer: An analysis of two cases of urban renewal in Istanbul. Urban Studies, 47(7), 1479-1499.

Lees, L. (2012). The geography of gentrification: Thinking through comparative urbanism. Progress in Human Geography, 36(2), 155-171.

Lefebvre, H. (1996). Writings on cities. Oxford: Blackwell. (Original work published in 1968)

Ley, D. (1996). The new middle class and the remaking of the central city. Oxford and New York, NY: Oxford University Press.

Linebaugh, P. (2010). Some principles of the commons. Counterpunch. Retrieved from www.counterpunch. org/2010/01/08/some-principles-of-the-commons

Lovering, J., \& Turkmen, H. (2011). Bulldozer neoliberalism in Istanbul: The state-led construction of property markets, and the displacement of the urban poor. International Planning Studies, 16(1), 73-96.

Luke, N., \& Kaika, M. (2019). Ripping the heart out of Ancoats: Collective action to defend infrastructures of social reproduction against gentrification. Antipode, 51(2), 579-600.

Massey, D. (2005). For space. London and Thousand Oaks, CA: Sage.

McFarlane, C. (2008). Urban shadows: Materiality, the 'southern city' and urban theory. Geography Compass, 2(2), 340-358.

Merrifield, A. (2011). The right to the city and beyond. City, 15(3/4), 473-481.

Mutfak. (2016). What's up in Mutfak. Migrant Solidarity Kitchen Newsletter, 1, 1-8.

Öz, Ö., \& Eder, M. (2018). 'Problem spaces' and struggles over the right to the city: Challenges of living differentially in a gentrifying Istanbul neighborhood. International Journal of Urban and Regional Research, 42(6), 1030-1047.

Papadopoulos, D., \& Tsianos, V. (2013). After citizenship: Autonomy of migration, organisational ontology, and mobile commons. Citizenship Studies, 17(2), 178-196.

Pinar, F. (2011, 26 January). Tarlabasi. So close yet so far away. Mashallah News. Retrieved from https:// www.mashallahnews.com/tarlabasi-so-close-yet-sofar-away

Potuoğlu-Cook, Ö. (2015). Hope with qualms: A feminist analysis of the 2013 Gezi protests. Feminist Review, 109(1), 96-123.

Purcell, M. (2002). Excavating Lefebvre: The right to the city and its urban politics of the inhabitant. GeoJournal, 58, 99-108. 
Roy, A. (2011). Slumdog cities: Rethinking subaltern urbanism. International Journal of Urban and Regional Research, 35(2), 223-238.

Sakizlioglu, N. B., \& Uitermark, J. (2014). The symbolic politics of gentrification: The restructuring of stigmatized neighborhoods in Amsterdam and Istanbul. Environment and Planning $A, 46(6), 1369-1385$.

Smith, N. (1999). Which new urbanism? The revanchist 90s. Perspecta, 30, 98-105.

Soja, E. (2009). The city and spatial justice. Spatial justice, 2009(1). Retrieved from shorturl.at/giuU8

Soja, E. (2010). Seeking spatial justice. Minneapolis, MN: University of Minnesota Press.

Talocci, G. (2011). A semiotics of urban voids and their resistance. The case of Istanbul. Paper presented at the "Urban Conflicts, Conflict in Cities" Conference in Queens University, Belfast.

Tarlabaşı Community Center. (2010). Who are we. Tarlabaşı Community Center. Retrieved from http:// www.tarlabasi.org/en/about-us/ttm

Trimikliniotis, N., Parsanoglou, D., \& Tsianos, V. (2015). Mobile commons, migrant digitalities and the right to the city. New York, NY: Palgrave MacMillan.

Tsavdaroglou, C. (2018a). The ecumenical "right to the city": Urban commons and intersectional enclosures in Athens and Istanbul. In P. A. d'Alençon, C. A. Cardoso, \& P. Horn (Eds.), Emerging urban spaces: $A$ planetary perspective (pp. 21-41). New York, NY: Springer.

Tsavdaroglou, C. (2018b). The newcomers' right to the common space: The case of Athens during the migrant crisis. ACME, 17(2), 376-401.

Tsavdaroglou, C. (2019). Reimagining a transnational right to the city: No Border actions and commoning practices in Thessaloniki. Social Inclusion, 7(2), 219-229.

Türkün, A., \& Şen, B. (2009). Radical transformations in historic urban centers and squatter housing neighborhoods in Istanbul. Paper presented at the RC21 Congress on inequality, inclusion and the sense of belonging, São Paulo, Brazil.

Ümit, A. (2014). Beyoğlu'nun en güzel abisi: Aşk, yaşamı; cinayet, ölümü sıradanlıktan kurtarır [When Pera trees whisper: Love keeps life from being ordinary. Murder saves death from mediocrity]. Istanbul: Everest Yayınları.

Ünsal, B. O. (2015). State-led urban regeneration in Istanbul: Power struggles between interest groups and poor communities. Housing Studies, 30(8), 1299-1316.

Wacquant, L. (2007). Territorial stigmatization in the age of advanced marginality. Thesis Eleven, 91, 66-77.

Young, I. M. (1990). Justice and the politics of difference. Princeton, NJ: Princeton University Press.

\section{About the Author}

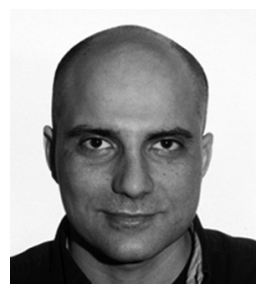

Charalampos Tsavdaroglou is a Marie Skłodowska Curie Fellow Postdoctoral Researcher at the University of Amsterdam. He holds a PhD from the School of Architecture, Aristotle University of Thessaloniki, Greece. His research interests include critical urban theory, autonomy of migration, common space, and urban social movements, intersectional, decolonial, and affective geographies, on which he has published several journal articles and book chapters in English and Greek. 